\title{
The English language in India: From Racial-Colonial to Democratic
}

\author{
Dr. Asima Ranjan Parhi \\ Professor and Head,Department of English Utkal University, Vani Vihar Bhubaneswar- \\ 751004,Odisha,India
}

\begin{abstract}
The teaching of English in Indian colleges received a major setback after the Indian independence because of the prevailing psychological attitude. Despite its status as the medium of instruction at the university level resulting in an adequate exposure to the English language, the barrier between the haves and have-nots of English led to a major divide in this country. A number of commissions and study groups stressed the need for the rationalization of the English curricula, textbooks and examinations. The 'service' nature of the teaching of English has been largely realized and also the need of the diversification of courses to suit to the divergent requirement of different categories of students of science, commerce and humanities and consequently of the suitable changes in teaching techniques. In fact, the teaching of English then started aiming at developing the communication skills in students. It is worthwhile to look at the language in question to be a tool for the market lending an adaptability to empower everyone rather than the strictly formal and curricular. All $19^{\text {th }}$ century linguists; from Humboldt to Sapir and Whorf emphasized upon linguistic relativity leading to bilingualism. Noam Chomsky spoke of linguistic creativity too. This romantic view against any positivist, essentialist linguistic determinism paves way for a better integrational method. This can pave way for the following argument to hold.

In India English print and electronic media have plenty of material which is suitable for the classroom teaching of English as it serves as the familiar context for the Indian learners of English. The entries are poetic, catchy and contain a deliberate method in them which could be utilized to teach not only the language but literary techniques, literary terms and theory of literature. It is fascinating to see how such data in the body of mass media (print and electronic), movies and popular songs generate suitable material for our classrooms in our context. This holds a promise of huge pedagogical implications for the teaching of English in India rather than following the traditional prescriptive skill building exercise.
\end{abstract}




\section{1-23 February, $2020 \quad$ Rome, Italy}

In this paper I suggest a model which is beyond the conventional approach to the teaching of theory, literature, and language. This approach can be systematically applied to evolve a pattern/ method that stresses the immediate context, that of specific language, society and culture.

Key words: Localising, standard English, nativise, Indian English, Englishes 